\title{
RELASI INTERNET DAN MEDIA SOSIAL DALAM PEMBENTUKAN BRAND AWARENESS, IMAGE DAN EXPERIENCE PRODUK ASING
}

\author{
Ina Nur Ratriyana \\ Prodi Ilmu Komunikasi, Universitas Atma Jaya Yogyakarta \\ ina_nur@staff.uajy.ac.id
}

\begin{abstract}
Abstrac
The effect of globalization on communication process appears especially in digital media which made communication exchange faster. Cultural process also create homogenization of product choice, when global brand looks more familiar than local brand. Internet and social media give an opportunity for consumer to access the product information and interact with them. Interactivity as part of digital media offers unlimited access and the power of word of mouth in terms of internet and social media. In the end, it will affect the brand awareness, image and attitude about product, especially in Generation $Y$ who are close with media digitalization itself as part of their life.
\end{abstract}

\begin{abstract}
Abstrak
Kemunculan globalisasi mempengaruhi proses komunikasi terutama dengan adanya media digital yang semakin mempercepat pertukaran informasi. Hal ini kemudian mempengaruhi proses kebudayaan, termasuk diantaranya mendorong homogenisasi dalam pemilihan produk, saat brand global menjadi lebih familiar dibandingkan dengan produk lokal. Internet dan media sosial muncul dan memberikan kesempatan pada konsumen untuk mengakses informasi sekaligus berinteraksi dengan produk. Interaktivitas merupakan sebuah hal baru yang ditawarkan oleh media digital. Internet dengan akses informasi yang tanpa batas dan media sosial dengan kekuatan word of mouth yang mempengaruhi pembentukan kesadaran, persepsi dan pembelian sebuah produk terutama di kalangan Generasi Y yang memiliki kedekatan dengan dunia digital.
\end{abstract}

Keywords: Globalization, Interactivity, Brand Awareness, Image, Experience,

\section{PENDAHULUAN}

Konsep globalisasi yang dicetuskan oleh McLuhan (1967), diamini oleh Giddens (1990) dan dikuatkan oleh Robertson (1992) dan Rantanen (2005) pada akhirnya diperkuat olehadanya eksistensi mediadan komunikasi. Dengan adanya fenomena globalisasi kemudian menguatkan konsep 'seolaholah' berada di ruang yang sama dengan pengalaman yang sedikit banyak juga sama. Kemunculan globalisasi ini pun akhirnya mempengaruhi budaya yang merupakan sebuah proses dinamis (Miller,1995) sehingga perbedaan kultur seringkali menyebabkan perbedaan perilaku konsumen di dalam dan antar negara.

Dalam hal ini, globalisasi pasar dan juga penerimaan secara global dari sebuah produk dan brand akan mendorong globalisasi dari perilaku dan attitude konsumen kemudian membentuknya dalam sebuah selera homogen, selera manusia secara global. Globalisasi telah dibawa melalui agenagennya dan disadari atau tidak berjalan 
berdampingan setiap hari dalam kehidupan manusia. Globalisasi-lah yang kemudian mendekatkan yang jauh dan menjauhkan yang dekat, membuat brand asing terasa lebih familiar dibandingkan dengan brand lokal karena bombardir iklan brand asing di media.

Seiring dengan globalisasi dan terbukanya pasar Indonesia, konsumen di dunia semakin bisa mengenali berbagai jenis brand, baikglobal maupun lokal. Brand global merupakan brand yang mengadopsi standard dari lingkungan di dunia untuk mencapai kesamaan standard produk (DogerliogliuDemir \& Tansuhaj,2011:667-683). Walaupun kemudian ada beberapa modifikasi dalam pemasaran demi memenuhi kebutuhan dan keinginankonsumendisebuahnegara, namun tetap saja brand global mempertahankan identitasnya.

Digital media menciptakan tidak hanya kesempatan namun juga tantangan bagi proses komunikasi pemasaran. Transparansi web membuat informasi online tersedia bagi semua audiens serta memperkuat kebutuhkan akan konsistensi perencanaan, desain, implementasi serta kontrol dari komunikasi pemasaran online (Gurau, 2008: 169-184). Di sisi lain, sejak adanya sharing dari channel dan audiens yang sama, pesan marketing dan juga PR dipublikasikan dalam web perusahaan sehingga menjadi lebih terintegrasi. Website perusahaan biasanya lebih terstruktur dengan berbagai kategori informasi, laporan finansial serta informasi lain untuk investor, lowongan pekerjaan, contact person serta link terkait namun kini telah berkembang sebagai saran berkomunikasi dengan konsumen itu sendiri.

Internet sendiri membantu brand untuk bisa mempelajari konsumen, membentuk brand awareness, membangun kedekatan dengan konsumen melalui keunikan isi informasi, fungsi dan personalisasi serta memastikan tersampaikannya brand promise (Simmons, 2007:544-562).

\section{Media Sosial}

Media sosial muncul sebagai media komunikasi digital yang cukup dominan dimana konsumen belajar, berbagi informasi dan berinteraksi dengan sebuah produk. Perkembangan sosial mediaini juga didukung adanya smartphones yang tersebar di seluruh dunia sehingga membuat pengguna bisa mengaksesnya kapan saja dan dimana saja. Media sosial memberikan kesempatan pada brand untuk berkomunikasi dua arah dengan konsumennya. Media sosial juga menjadi salah satu channel referensi dan berbagi informasi antara satu dengan yang lain (Simon et.al., 2016: 27-41).

Sosial media merupakan aplikasi berbasi internet yang memberikan kesempatan penggunakanya untuk melakukan kreasi dan user generated content. Jumlah iklan pun semakin meningkat dengan digunakannya Facebook, Twitter dan Pinterest untuk mempromosikan sebuah brand. Pengguna media ini sendiri didominasi oleh remaja dan generasi muda yang mulai bergeser dari media tradisional ke media internet. Di sisi lain, konsumen juga bisa secara leluasa dan terbuka memberikan feedback pada perusahaan terutama yang terkait dengan brand image dan awareness (Seung \& Jin, 2014: 181-195) yang kemudian menjadi keunggulan media sosial yang dimanfaatkan oleh brand.

\section{Terpaan Media}

Terpaan media, dalam hal ini media digital yang dipetakan dalam internet dan media sosial, merupakan suatu proses dimana terjadi respon kognitif atau pemikiran ketika mereka membaca, melihat atau mendengar komunikasi tersebut. Efek yang diterima komunikan sebagai hasil dari exposure (terpaan) berupa pesan dari komunikator akhirnya mendapat respon komunikasi. Exposure di sini adalah kehadiran sebuah informasi kepada seorang audiens. Sedangkan menurut Montgomery dan Amstrong (1970:26), exposure merupakan suatu variabel konseptual dimana terjadi kontak seorang konsumen dengan informasi 
mengenai brand pada berbagai media. Dalam teori Stimulus-Response dan Hierarchy of Effect, exposure menjadi suatu variabel penting yang mendahului bagian kejadian selanjutnya. Exsposure seorang audiens atau target konsumen terhadap suatu produk, biasanya melalui iklan, merupakan langkah awal untuk membuka ruang dalam benak mereka tentang eksistensi suatu merk. Tellis (1988:25) menyatakan bahwa exsposure terhadap suatu iklan dapat memperkuat preferensi audiens akan suatu merk. Variabel dari terpaan media adalah frekuensi, durasi, dan perhatian.

Selera konsumen berubah dari waktu ke waktu, termasuk di dalamnya dipengaruhi oleh beragam informasi yang berkembang secara cepat di era internet ini. Perkembangan cepat internet dalam beberapa tahun terakhir ini telah mengubah prosedur komunikasi klasik (Gurau, 2008: 169-184) karena adanya tiga karakteristik yang spesifik dan hidup berdampingan sehingga membedakannya dengan channel komunikasi yang lain:

a. Interactivity: internet menawarkan berbagai kemungkinan akan komunikasi interaktif, bertindak bukan hanya sebagai penghubung belaka namun sebagai agen komunikasi.

\section{Gambar 1. Pilar i-Branding (Simmons,2007:545)}

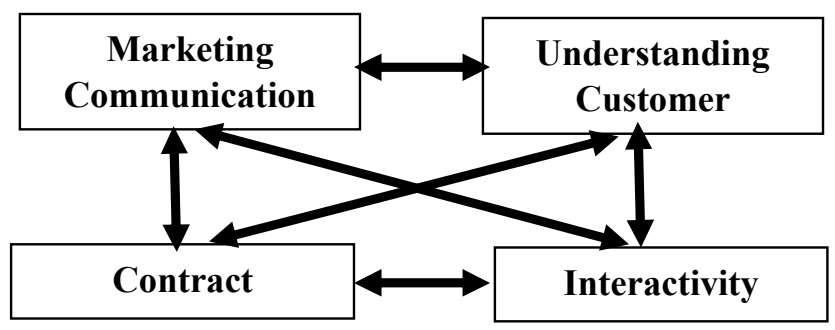

b. Transparency: informasi yang dipublikasikan secara online bisa diakses dan dilihat oleh pengguna internet yang lain.

c. Memory: web merupakan sebuah channel tidak hanya untuk mentrasmisikan informasi namun juga menyimpannya, dengan kata lain informasi yang dipublikasikan dalam webakan tersimpan dalam memory network hingga kemudian dihapus.

Adanya konvergensi media, tekhnologi dankomunikasisepertiinternet, international magazine, channel tv asing akan membuat preferensi, cita rasa dan attitude konsumen bersifat homogen (Douglas \& Craig, 1997: 379-395). Terstimulasi oleh perkembangan media, konsumen di negara berkembang mulai menyukai produk mewah daripada memikirkan kebutuhan dasar terlebih dahulu (Belk, 1988: 139-168).

Dalam menghadapi realitas konsumen, brandharusbisaberadaptasiakanrealitasbaru tentang bagaimana audiens mendapat dan menggunakan informasi (Gurau,2008:169184), dimana konsumen saat ini memiliki kecenderungan sbb.:

a. Audiens terkoneksi dengan perusahaan: channel komunikasi tradisional yang searahdimanaperusahaanberkomunikasi dan audiens mendapatkan informasi. Ketika komunikasi dianggap sebagai proses dua arah, perusahaan memiliki sumber untuk mengirimkan informasi pada audiens melalui pipa yang sangat besar sedangkan audiens hanya memiliki pipa yang sangat kecil untuk berkomunikasi kembali. Saat ini, channel komunikasi melalui network, bukan lagi pipa, sehingga mampu menutup batasan antara audiens dan perusahaan. Semua yang terlibat dalam mengirim pesan hanya tinggal satu klik jauhnya dari audiens (Gurau,2008:169-184).

b. Audiens terhubung satu sama lain: saat ini, aktivitas perusahaan bisa didiskusikan dan juga didebatkan di internet tanpa pengetahuan tertentu akan perusahaan. Dalam lingkungan baru ini, semua orang merupakan komunikator dan perusahaan hanya merupakan bagian dari network (Gurau,2008: 169-184).

c. Audiens memiliki akses pada informasi lain: di masa lalu hal ini sulit dilakukan karena minimnya informasi namun saat ini sangat mudah untuk mengakses berbagai sumber informasi dari internet. 
Semua statement bisa dibedah, dianalisis, didiskusikan dan juga ditantang dalam hitungan jam.

d. Audiens menarik informasi: jalur komunikasi digital telah meningkat sejalan dengan jumlah channel komunikasi. Saat ini kita mendapat pesan dari berbagai channel media seperti email, voice mail, fax, handphone, post, televisi, radio, internet, dll. Hasilnya, media yang digunakan untuk memproduksi channel komunikasi yang efisien bagi praktisi sekarang lebih seperti halnya noise dimana konsumen sendiri yang harus melakukan filter. Di sisi lain, lingkungan network menyediakan audiens dengan model baru, dimanakonsumencenderung memilih informasi yang sesuai dengan ketertarikan dan kebutuhan mereka. Pada akhirnya network berusaha untuk berada dimana audiens bisa menemukannya serta harus sesuai atau disesuaikan untuk konsumen tsb. (Gurau, 2008: 169-184).

\section{Brand Awareness, Image dan Experience}

Sudut pandang konsumen dalam memilih keputusan berdasar pada konsep AIDA (Attention, Interest, Desire, Action) yang merupakan model penerimaan pesan berdasarkan proses informasi yang bersifat linear (Moriarty et.al., 2012; Bray, 2008). Konsumensecaraaktifterusmenerusmencari dan menerima stimulus dari lingkungannya untuk kemudian menghasilkan keputusan dimana kemudian pendekatan ini dikenal sebagai Psikologi Kognitif (cognitive pshycology). Pendekatan ini mencoba menjelasan bagaimana konsumen memroses informasi sebelum melakukan pemilihan (Heding et.al., 2009). Persepsi sendirilahyang kemudian paling berperan dalam pemrosesan informasi dalam benak konsumen sehingga dalam penelitian ini peneliti akan melihat stimulus yang didefinisikan sebagai media sosial serta relasinya pada pembentukan persepsi konsumen.
Gambar 2. Psikologi Kognitif Konsumen

(Heding et.al.,2009)

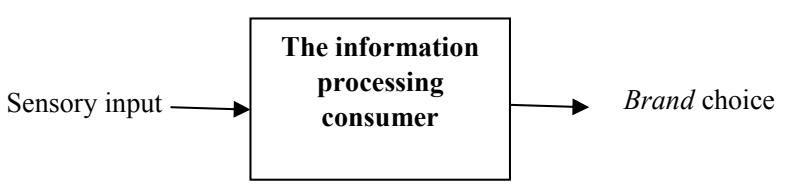

Dalam pendekatan ini, faktor seperti kemampuan memroses, motivasi, atensi, persepsi, informasi dan evaluasi merupakan proses pembentukan pilihan (Heding et.al., 2009). Pendekatan ini juga menjelaskan fenomena pembentukan persepsi oleh konsumen dimana setiap persepsi yang dihasilkan berdasarkan stimulus yang dilakukan secara berbeda-beda oleh setiap individu.

Prinsip memori dan struktur kognitif merupakan hasil dari terpaan informasi mengenai produk di internet dan media sosial akan membentuk brand awareness di benak konsumen (Heding et.al., 2009). Brand awareness merupakan saat brand berada dalam tahap mengetuk kesadaran konsumen sehingga konsumen dapat mengenal atau minimal mengetahui sedikit mengenai brand tsb. Brand awareness merupakan komponen penting dari brand equity dimana sebuah brand dianggap memiliki awareness ketika konsumen mampu mengingat (brand recall) dan mengenali (brand recognition) produk tsb.dibandingkan dengan produk yang lain (Hamidi et.al.,2010: 250-267).

$\mathrm{H}_{1}$ : Semakin tinggi terpaan internet dan media sosial, semakin baik brand awareness produk. Selanjutnya, persepsi disini dipetakan melalui brand image yang dipahami sebagai "perceptions about brand as reflected by the brand association held in consumen memory" (Hamidi et.al.,2010:250267). Brand image merupakan sesuatu yang terefleksi dari produk yang diyakini oleh konsumen melalui proses panjang untuk membangun karakter brand yaitu: (i) keunggulan brand (favorability of brand association); (ii) kekuatan brand (strength of brand association) dan (iii) keunikan brand (uniqueness of brand association). Keunikan brand akan memberikan kesan berbeda bagi konsumen sehingga konsumen akan sulit lupa karena keunikannya dibandingkan 
dengan produk lain yang nyaris serupa. Kekuatan brand merupakan seberapa besar dan kuat terpaan brand itu sehingga mampu bertahan dalam benak konsumen, salah satu hal yang mempengaruhi kekuatan brand adalah media. Sedangkan keunggulan brand merupakan kelebihan produk sehingga dapat memenuhi kebutuhan dan keinginan konsumen.

$\mathrm{H}_{2}$ : Semakin tinggi terpaan internet dan media sosial, semakin baik brand image produk. Level dari pemrosesan pengaruh dari media bisa diasosiasikan dengan efek iklan. Misalnya, konsumen mencapai level yang lebih tinggi dalam proses, maka mereka akan mengelaborasi dan menghubungkan informasi brand yang ada dalam iklan. Perhatian dan proses meningkatkan memori dari informasi brand seperti nama dan klaim produk (Maclnnis et.al.,1991:33-34). Penelitian juga menyarankan tingginya level proses yang akan menghasilkan brand experience yang lebih bertahan lama, stabil dan mudah diakses. Beberapa perilaku akan semakin memperkuat mempengaruhi intensi pembelian dan kemungkinan akan berlawanan dengan klaim kompetitor.

Berikut ini merupakan tahapan pembuatan keputusan sebagai bagian pemetaan brand experience yang dijelaskan oleh Moriarty et.al. (2012) dan Bray (2008):

1. Need recognition

Merupakan fase yang penting, dimana salah satu tujuan iklan dalam media adalah menstimulasi kebutuhan ini. Dalam tahapan ini konsumen menyadari kondisi mereka saat ini dan kondisi yang sebenarnya mereka inginkan.

\section{Information search}

Pencarian informasi ini bisa dilakukan secara internal yakni dengan konsumen mengakses bank memori mengenai pengalaman masa lalu atau juga external. Dalam pencarian informasi secara eksternal, iklan sangat membantu menyediakan informasi yang mudah dicari dan diingat. Para pencari informasi didorong untuk mengetahui semua yang mereka bisa mengenai produk sebelum melakukan pembelian, terutama pembelian besar. Sedangkan impulse buyer tidak perlu terlalu banyak berfikir karena dorongannya adalah lebih pada haus atau lapar. Informasi sendiri disampaikan dalam lima tahapan yakni exposure, attention, comprehension, acceptance dan retention (Blackwell et.al. dalam Bray, 2008).

\section{Evaluation of alternatives}

Merupakan tahapan dimana konsumen membandingkan berbagai produk dan feature untuk memperpendek daftar pilihan. Konsumen memilih feature tertentu karena mereka merasa perlu menggunakannya untuk alternatif. Iklan penting dalam proses evaluasi karena membantu konsumen untuk memperbandingkan feature produk.

4. Purchase decision

Biasanya konsumen akan memilih brand terlebih dahulu dan kemudian menentukan dari mana dia akan membelinya.

\section{Post-purchase evaluation}

Merupakan langkah terakhir dari proses rasional. Setelah kita membeli sebuah produk, terutama produk besar/mahal, maka kita kemudian melakukan evaluasi keputusan. Apakah produk tersebut sudah sesuai dengan ekspektasi, apakah produk sudah cukup memuaskan, kemudian konsumen mengambil kesimpulan berdasarkan pengalamannya untuk menyimpan, mengembalikan, membeli kembali atau tidak membeli lagi produk tsb. Konsumen juga lebih sering mencari tahu informasi seputar produk untuk meyakinkan pembeluannya atau memberikan garansi pada ketakutannya apabila pembelian yang dilakukan ternyata salah.

$\mathrm{H}_{3}$ : Semakin tinggi terpaan internet dan media sosial, semakin tinggi brand experience produk. 


\section{Merk Global}

Brand Magnum dipilih karena merupakan bagian dari brand global Unilever yang mengedepankan lifestyle kelas menengah atas dengan generasi muda sebagai target marketnya. Magnum sendiri merupakan sebuah fenomena tersendiri di mana produk tersebut mampu mengubah mindset kebanyakan orang, ice cream tidak lagi dilihat hanya sebagai konsumsi anakanak namun merupakan gaya hidup. Untuk menciptakan image ice cream sebagai sebuah lifestyle kelas menengah atas, Magnum memilih brand ambassador artis papan atas seperti Marissa Nasution, Olla Ramlan dan juga Raisa yang dianggap sesuai dengan image Magnum sendiri. Kehidupan artis yang mewah diperlihatkan dalam iklannya dengan harapan bisa menarik perhatian konsumen Indonesia.

Magnum menggunakan komunikasi interaktif dimana brand berusaha mengirimkan pesan langsung ke konsumen berusaha menangkap respon langsung dari sumbernya. Dalam kegiatannya, Magnum bertumpu pada media sosial dan menerapkan strategi word of mouth (WOM). Magnum secara intensif menggunakan media sosial seperti akun twitter@MyMagnumID, facebook 'Magnum Indonesia' dan website www.mymagnum.co.id sehingga semakin mempercepat persebaran informasi. Setiap informasi yang muncul tersebar demikian cepat di dunia maya dan termasuk juga berdampak di dunia nyata.

Di tahun 2014, Magnum meluncurkan kampanye Magnum Pink \& Black dengan voting nasional melalui tagar \#MagnumVote untuk menentukan mana produk yang lebih populer, promo \#MagnumWonders untuk mendapatkan tiket launching produk dan tagar \#MagnumPromo untuk memenangkan hadiah premium.

Penggunaan media sosial memiliki tujuan untuk memotivasi respon sesegera mungkin dengan informasi yang bersifat cepat dan bisa dihitung hasilnya. Informasi yang disampaikan melalui media sosial bisa menyampaikan pesan dalam hitungan detik dan juga memiliki fungsi users generated content atau disampaikan secara multiple oleh users yang lain sehingga semakin mempercepat persebarannya. Sedangkan untuk hasilnya juga bisa diketahui dengan jelas, misalnya untuk kampanye national voting Magnum Pink \& Black bisa mendapatkan hingga 5.200.ooo voters hanya dalam jangka waktu 1 bulan.

Media sosial menjadi salah satu andalan komunikasi pihak Magnum. Melalui media sosial @MyMagnumID, Magnum memiliki 54.894 follower dengan rata-rata intensitas 6-7 tweets per hari. Intensitas interaksi melalui media sosial sangat tinggi dan dianggap sangat efektif karena sesuai dengan target market Magnum (Majalah Mix, 2014).

Magnum memanfaatkan media sosial dalam kegiatan komunikasi pemasarannya, salah satunya adalah Facebook yang saat ini diakui sebagai salah satu sosial media paling berpengaruh terutama apabila kita menyadari "the power of like" yang dimiliki oleh Facebook. Sosial media menjadi sarana yang penting dalam mendukung proses persebaran pesan, terutama iklan dan juga event yang diadakan oleh Magnum untuk menjangkau konsumen mereka terutama pengguna media sosial. Magnum juga memanfaatkan media sosial secara serius dalam strategi marketingnya karena memang $25 \%$ dari pengguna internet di Indonesia adalah dewasa berusia 25 tahun ke atas, yang mana juga sesuai dengan target market Magnum. Twitter dan Facebook memberikan kesempatan pada brand untuk membangun hubungan dengan konsumen sedangkan marketing above the line digunakan untuk membangun awareness (Grazella, 2012).

\section{Generasi Y}

Banyak literatur yang menunjukkan bahwa brand global diterima secara positif oleh konsumen (Dogerliogliu-Demir \& Tansuhaj, 2011: 667-683) dan biasanya konsumen muda tertarik dengan pesona brand global tersebut dengan tujuan untuk menaikkan status dirinya. Generasi Y selain menjaditargetpasarMagnumjugamerupakan 
generasi yang mengenal internet dan gadget semenjak lahir sehingga familiar dengan brand global dibandingkan generasi lainnya. Pada akhirnya, Generasi Y pun memiliki kecenderungan untuk selalu membeli barang-barang berbau tekhnologi ataupun barang ber-brand untuk mendapatkan kelas dan kualitas yang diinginkan (McCrindle, 2007). Hal ini juga diperkuat dengan penelitian sebelumnya yang dilakukan oleh Sun (2011) berusaha memotret fenomena konsumerisme generasi muda China yang begitu tinggi. Dari hasil penelitian tersebut ditemukan bahwa para konsumen memilih untuk membeli produk yang mahal untuk mengekspresikan diri supaya bisa diterima oleh peer group-nya.

Populasi dari penelitian ini merupakan Generasi $Y$ yang lahir antara tahun 1980 hingga 1996 atau juga dikenal sebagai Echo Boomers/Me Generation. Generasi ini dianggap mewakili target market dari brand Magnum yang berusia antara 17-37 tahun (Moriarty et.al., 2012; Sun, 2011).

Generasi Y menjadi kelompok yang penting karena saat ini merupakan orang dewasa muda berusia sekitar 19-35 tahun yang ingin diraih oleh marketer dalam brand (Moriarty et.al., 2012; Sun, 2011). Mereka dianggap penting oleh marketer karena jumlahnya yang besar dan generasi ini juga dikenal sebagai Digital atau Net Generasi atau Dot.com Generasi karena mereka tumbuh dengan komputer, email dan telephone celluler serta lebih paham tekhnologi daripada saudaranya yang paling tua atau orang tuanya. Generasi Y juga memiliki kecenderungan untuk membeli barang-barang bertekhnologi baru dan barang-barang yang berkelas. Faktanya, 6o\% Generasi Y dilahirkan dari ibu pekerja dan juga 6o\% diantaranya memiliki komputer di rumah (Len, 1997). Hal inilah yang memicu kedekatan generasi ini baik dengan komputer maupun internet.

Selain kedekatannya dengan komputer, Generation Y juga dianggap sebagai generasi yang boros dibandingkan generasi lainnya. Rata-rata Generation Y tidak memiliki rencana investasi ataupun tabungan. Mereka akan lebih memilih untuk membelanjakan kelebihan uangnya untuk produk mewah atau menikmati hidup (Sun, 2011). Dikarenakan memiliki uang yang cukup banyak dibandingkan generasi sebelumnya, bahkan sebuah penelitian menyatakan 1 dari 6 orang anak memiliki kartu kreditnya sendiri, sehingga memudahkan marketer untuk menjual produk pada mereka, terutama yang mewabah saat ini adalah online shopping (Morton, 2002). Di sisi lain, perbankan mempermudah mereka untuk mengaksespinjaman dan juga kreditsehingga membuat mereka lebih memungkinkan untuk berbelanja. Barang mewah menjadi salah satu cara untuk melepas penat setelah menghadapi stress pekerjaan. Karakteristik ini juga dianggap oleh peneliti sesuai dengan target market Magnum dengan tagline "pleasureseekers"yangmencintaikemewahan dan cenderung menikmati hidup.

Dalam hal penggunaan media sebagai sumber informasi, dibutuhkan riset mendalam untuk mengetahui mana yang sering diakses oleh Generasi Y karena selera mereka cukup beragam (Morton,2002). Selain itu, Generasi Y juga dianggap sebagai konsumen yang plin-plan, hal ini juga mempengaruhi penggunaan internet karena masing-masing memiliki preferensinya sendiri-sendiri.

\section{METODE}

Metode penelitian kuantitatif yang akan digunakan adalah metode penelitian survey (De Vaus,1991) yang memiliki fungsi utama untuk mengumpulkan informasi dari responden dengan menggunakan kuesioner. Metode survey sendiri digunakan untuk mendapatkan data yang akurat untuk mengetahui berbagai persepsi konsumen mengenai produk. Dalam bidang marketing, penelitian kuantitatif digunakan untuk mendapatkan data numerik mengenai konsumen, perilaku dan juga pengetahuan, selain itu juga didesain untuk secara akurat memprediksi sesuatu misalnya persepsi ataupun perilaku (Moriarty et.al., 2012).

Populasi dari penelitian ini merupakan 
Generasi Y di kota Jakarta dan Yogyakarta. Generasi $Y$ merupakan generasi yang lahir antara tahun 1980 hingga 1996 juga dikenal sebagai Generasi Digital atau Net Generation karena mereka tumbuh dengan komputer dan lebih paham tekhnologi. Generasi Y juga memiliki kecenderungan untuk membeli barang-barang mewah yang menjadi salah satu cara untuk melepas penat setelah menghadapi stress pekerjaan. Saat ini grup ini merupakan orang dewasa muda yang ingin diraih oleh marketer dalam brand (Moriarty et.al., 2012; Sun, 2011). Generasi ini juga cukup mewakili target market dari brand Magnum yang memiliki tagline "pleasure seekers" yang mencintai kemewahan serta berada di rentang usia 19-30 tahun.

Dari populasi tsb. akan diambil non-probability sampling yaitu dengan menggunakan quota sampling sejumlah 384 orangyang dibagi secara proporsional dengan asumsi $95 \%$ confidence level dan 5\% margin of error (Sue dan Ritter,2012). Jumlah sampel yang diambil sesuai dengan minimal sampel yang diharapkan berdasarkan margin of error yaitu 384 orang sehingga angka ini dianggap representatif untuk penelitian dengan metode survey. Non-probability sampling merupakan metode pengambilan sampling yang disesuaikan dengan pertimbangan dan tujuan peneliti.

Data-data yang diperoleh dari hasil survey lapangan kemudian akan diolah dengan program Statistical Product and Service Solution (SPSS) 21. Beberapa uji yang digunakan adalah uji validitas, reabilitas, hierarchial regression analysis serta analysis covariance.

Uji validitas digunakan untuk menilai item-item pertanyaan dalam alat pengukur layak digunakan atau tidak (Priyatno,2012). Hasil dari uji validitas menujukkan bahwa variabelyangdigunakanmemenuhisyaratdan dianggap layak untuk digunakan $(\alpha>0.30)$. Dengan demikian setiap butir pertanyaan dianggap kuat untuk dipergunakan dalam penelitian ini.

Selain uji validitas juga dilakukan uji reliabilitas untuk mengetahui konsistensi alat ukur yang digunakan, yaitu kuesioner dalam penelitian ini, dengan menggunakan koefisien Alpha Cronbach yang merupakan salah satu koefisien reabilitas yang paling banyak digunakan dengan skala pengukuran yang dianggap reliabel bernilai Alpha Cronbach $>0.70$ (Nunally \& Bernstein dalam Uyanto,2006). Selain itu uji reabilitas juga digunakan untuk melihat apakah alat dalam penelitian ini bisa dipergunakan kembali dalam kasus yang lain (Priyatno,2012). Hasil uji reabilitas dari instrument penelitian ini $(\alpha=0.831)$ dapat diisimpulkan bahwa instrument penelitian reliable dan konsisten untuk diterapkan pada kasus yang lain, tidak hanya berlaku terbatas pada penelitian ini saja.

Analisis regresi hierarki (hierarchial regression analysis) dilakukan untuk memprediksi hubungan variabel dependent dan independent berdasarkan prediksi pengaruh lebih dari 1 variabel, yaitu variabel kontrol maupun variabel antara (Uyanto,2006; Widhiarso,2011).

\section{HASIL DAN PEMBAHASAN}

Terpaan media merupakan salah satu komponen penting dalam pembentukan persepsi. Persepsi dalam studi komunikasi dilihat melalui Social Cognitive Theory (Miller, 200o) dimana aksi dari manusia merupakanresponsdaristimulieksternalatau lingkungannya. Perilaku ini menggunakan model S-R (Stimulus-Response) yang menyatakan bahwa manusia belajar dengan adanya sistem reward $\mathcal{E}$ punishment sebagai hasil respon dari stimulus tertentu. Namun, karena tidak memungkinkan untuk setiap konsumen mengalami experience secara langsung maka kemudian mereka belajar dengan cara melihat perilaku orang lain dan kemudian menirunya.

Dalam pembentukan brand awareness, terpaan internet dan media sosial secara positif mempengaruhi pembentukan brand awareness $(\alpha=0.000 ; \mathrm{F}=91.490)$ dengan efek (effect size) sebesar 19,5\%. Hal ini menunjukkan bahwa media internet dan sosial memberikan informasi yang cukup besar dalam membantu pembentukan brand 
awareness di kalangan konsumen. Dengan demikian berarti hipotesis pertama yang berbunyi 'semakin tinggi terpaan internet dan media sosial, semakin baik brand awareness produk' bisa diterima. Tentunya dalam hal ini perlu diingat banyak faktor dan media lain yang juga memiliki kemampuan mendorong terbentukanya brand awareness misalnya saja televisi, baliho ataupun media cetak yang hingga kini tidak bisa kita pungkiri keberadaannya.

Terpaan media, dalam hal ini berbagai informasi dan iklan yang berkembang di media internet menjadi faktor pembentuk persepsi seseorang. Dari hasil analisis regresi ditemukan bahwa terpaan internet dan media sosial secara positif mempengaruhi pembentukan persepsi konsumen ( $\alpha=0.000$; $\mathrm{F}=82.88$ ) dengan ukuran efek (effect size) sebesar $18,2 \%$. Hal ini menunjukkan bahwa persepsi dipengaruhi cukup kuat oleh terpaan media internet karena menyumbang efek sebesar $18 \%$ walaupun kemudian tentunya ada faktor-faktor eksternal yang mempengaruhi persepsi. Dengan demikian hipotesiskeduayang berbunyi 'semakin tinggi terpaan internet dan media sosial, semakin baik brand image produk' diterima. Namun pada dasarnya, seseorang akan melihat dunia dan membuat asumsi berdasarkan apa yang orang lain lakukan (Schmitz, 2012) sehingga penggunaan iklan di media internet yang banyak diakses akan membuat konsumen memiliki brand image yang lebih tinggi dibandingkan produk lainnya.

Namun perlu dilihat kembali bahwa proses pembentukan persepsi dalam brand image akan mengalami distorsi karena di dalam proses penerimaan informasi, terjadi penghapusan informasi dikarenakan fisik manusia yang terbatas. Ada 3 tahap proses persepsi: memilih informasi, mengorganisasi dan menginterpretasi. Setiap persepsi yang kita peroleh tidak selalu sempurna karena adanya proses penghapusan (deletion), penyimpangan (distortion) dan generalisasi (generalization) (Hybels \& Weaver, 2004). Sehingga kemudian bisa dilihat kembali bahwa dari tahap brand awareness hingga terbentuknya persepsi brand terdapat pengurangan efek sebesar 1,3\% yang bisa dilatarbelakangi berbagai hal seperti latar belakang budaya, pendapatan dan pendidikan.

Tabel 1. Intensitas Akses Media

\begin{tabular}{|c|l|r|}
\hline Media & Intensitas per hari & Prosentase \\
\hline Internet (non & Tidak pernah & $3.4 \%$ \\
\cline { 2 - 3 } media sosial) & $<1$ jam & $8.4 \%$ \\
\cline { 2 - 3 } & $1-2$ jam & $24.8 \%$ \\
\cline { 2 - 3 } & $3-5$ jam & $26.4 \%$ \\
\cline { 2 - 3 } & $>5$ jam & $37.1 \%$ \\
\hline Media sosial & Tidak pernah & $1.9 \%$ \\
\cline { 2 - 3 } & $<1$ jam & $1.6 \%$ \\
\cline { 2 - 3 } & $1-2$ jam & $6.3 \%$ \\
\cline { 2 - 3 } & $3-5$ jam & $23 \%$ \\
\cline { 2 - 3 } & $>5$ jam & $26.9 \%$ \\
\hline
\end{tabular}

Berdasarkan tabel di atas, kebanyakan responden mengakses internet (website, berita online, email, dll.) selama 1-2 jam (24.8\%), 3-5 jam (26.4\%) hingga $>5$ jam (37.1\%) per hari. Sedangkan dalam akses media sosial, hingga $49.4 \%$ mengakses di atas 3 jam per hari. Hal ini menunjukkan bahwa internet dan media sosial tidak bisa lagi dipisahkan dalam kehidupan sehari-hari konsumen. Mereka mengakses internet tidak hanya untuk mencari informasi namun juga bersosialisasi dengan teman dan keluarga. Hal ini termasuk juga kemudian berperan penting dalam pembentukan persepsi brand yang terjadi dari pesan mulut ke mulut (word of mouth). Word of mouth juga bisa terbentuk dari ornag-orang terdekat (peer group) serta bisa juga melalui orang-orang yang tidak dikenal sebelumnya misalnya saja follower akun instagram, member milis atau club website, grup diskusi, dan lain-lain yang terbangun melalui jaringan internet.

Berdasarkan rentang usianya, responden dalam penelitian ini terbagi menjadi dua kelompok besar. Pertama, mahasiswa (usia 19-24 tahun) yang merupakan kelompok Generasi Y yang lebih muda. Mereka masih fokuspadapendidikandanbelumberorientasi pada uang. Kehidupan sehari-hari mereka ditopang oleh orang tua sehingga bisa jadi mereka lebih selektif dalam pembelian. Mereka banyak menggunakan internet untuk keperluan mencari informasi seputar 
perkuliahan dan juga hiburan.

Kelompok kedua adalah pekerja produktif muda (usia 24-30 tahun) dengan karakteristikyanglebihdewasa.Sisa-sisamasa perkuliahan masih membekas namun mereka telah lebih mandiri dengan pemikiran yang lebih terbuka. Dengan adanya kemandirian dalam finansial, seringkali mereka lebih boros secara finansial, terutama memenuhi kebutuhan untuk bersenang-senang dan membeli barang mewah. Mereka banyak menggunakan internet untuk keperluan mencari informasi seputarpekerjaan, hiburan dan juga bersosialisasi dengan teman.

Dari segi usia, responden dengan usia 25, 26, 27 dan 28 tahun memiliki persepsi yang relatif lebih baik dibandingkan usia lainnya dan memberikan sumbangan sebesar $34.3 \%$ terhadap pembentukan persepsi konsumen. Apabila dikaitkan dengan intensitas responden di usia ini dalam mengakses internet dan media sosial, ternyata kebanyakan dari mereka di rentang usia 25-27 tahun menghabiskan waktu 3-5 jam (42\%) dan $>5$ jam (66\%) per hari. Hal ini menunjukkan bahwa responden di usia ini yang sebanyak 74,3\% diantaranya bekerja di sektor swasta cukup memperhatikan perkembangan yang ada di dunia maya, baik website maupun berita online maupun media sosial. Mereka sangat memperhatikan perkembangan yang terjadi di sekitarnya termasuk di kalangan teman dan keluarga serta ingin selalu update tentang arus yang ada.

Hal ini cukup menarik karena responden di usia ini dalam kondisi yang sangat produktif serta biasanya sibuk dengan urusan pekerjaan. Namun di sisi lain, intensitas media sosialnya pun cukup tinggi. Fenomena ini menunjukkan bahwa media sosial bisa jadi menjadisarana pelepas penatsetelah seharian berkutat dengan pekerjaan. Responden usia usia 25-28 menganggap media sosial sebagai pelepas penat dan juga sarana penyambung kabar dengan rekan-rekan lainnya yang tidak bisa dijangkau karena kesibukan.

Apabila menilik dari jenis kelamin responden, tidak ada perbedaan yang signifikan antara laki-laki dan perempuan dalam mengakses internet. Sebanyak 132 orang responden laki-laki $(34,3 \%)$ dan 129 orang responden perempuan (33,5\%) mengakses internet dan media sosial lebih dari 3 jam per hari. Baik laki-laki dan perempuan sama-sama mengakses internet dan media sosial secara intensif. Walaupun kemudian apabila ditelusuri lebih jauh lagi, laki-laki lebih banyak mengakses berita, games dan film sedangkan perempuan cenderung membaca artikel yang terkait dengan fashion atau online shop.

Tabel 2. Akses Media Sosial

\begin{tabular}{|l|r|}
\hline \multicolumn{1}{|c|}{ Media sosial } & Prosentase \\
\hline Path & $26.8 \%$ \\
\hline Facebook & $37.4 \%$ \\
\hline Instagram & $19.6 \%$ \\
\hline Twitter & $14.3 \%$ \\
\hline Lainnya & $1.9 \%$ \\
\hline
\end{tabular}

Dari tabel di atas, terlihat bahwa media sosial yang paling banyak diakses oleh responden adalah Facebook (37.,\%) dan Path (26,8\%). Facebook sendiri merupakan media sosial terbesardidunia dengan pengguna aktif hingga 60 juta per bulan. Indonesia sendiri menduduki peringkat ketiga pengguna Facebbok tertinggi di dunia dengan 63 juta orang pengakses di tahun 2015 (Noviandasari, 2015). Dengan penetrasi tertinggi di dunia, tidak heran kemudian banyak brand yang mencoba mematangkan komunikasinya melalui Facebok. Hal ini juga merupakan salah satu strategi yang dilakukan oleh Magnum dalam mendekati konsumennya dengan menggunakan Magnum Indonesia dalam Facebooknya.

Path sendiri merupakan sebuah aplikasi media sosial yang muncul sejak tahun 2010. Berpusat di San Fransisco, Path mengedepankan misi mereka sebagai sebuah tekhnologi dan desain yang membantu penggunanya untuk menjadi lebih bahagia, bermakna dan terkoneksi satu dengan yang lain (www.path.com). Digunakan oleh lebih dari 4 juta pengguna di seluruh dunia, tidak herankemudianIndonesiamendudukinegara pertama sebagai pengguna Path terbanyak di dunia. Fenomena ini sekali lagi menegaskan 
kedekatan masyarakat indonesia dengan dunia digital dan kemudian lebih mudah untuk mendekati mereka melalui media digital dibandingkan media konvensional lainnya terutama bagi Generasi $\mathrm{Y}$ yang memang relatif lebih familiar dengan gadget dan tekhnologi.

Terkait dengan pembelian, terpaan media termasuk iklan dan informasi yang ada di dalamnya diyakini mampu mempengaruhi pembelian. Dari hasil analisis regresi ditemukan bahwa terpaan internet dan media sosial secara positif mempengaruhi pembelian produk $(\alpha=0.000 ; \mathrm{F}=41.578)$ dengan ukuran efek (effect size) sebesar 9,9\% saja. Dengan demikian hipotesis ketiga yang berbunyi 'semakin tinggi terpaan internet dan media sosial, semakin tinggi brand experience produk' bisa diterima. Walaupun kemudian patut dilihat kembali bahwa nilai efek semakin mengecil pada tahapan pembelian. Hal in tentunya terkait berbagai pertimbangan yang dilakukan oleh konsumen sebelum melakukan pembelian termasuk di dalamnya terdapat proses evaluasi alternatif dari produk yang ada di pasaran. Bisa jadi produk tersebut sesuai dan diinginkan namun tidak sesuai secara harga sehingga kemudian membatasi pembelian konsumen.

\section{SIMPULAN}

Internet dan media sosial memberikan sumbangsih terhadap perubahan pendekatan produk kepada konsumen. Sadar atau tidak, dengan keberadaan internet dan media sosial memberikan kesempatan pada brand untuk berkomunikasi dua arah dengan konsumennya. Konsumen bisa mendapatkan referensi dan berbagi informasi antara satu dengan yang lain yang kemudian memperkuat kesadarannya akan sebuah brand hingga akhirnya bisa membentuk keputusan pembelian.

Faktor lain yang mempengaruhi pembentukan brand image dari sisi eksternal misalnya media konvensional dan luar ruang serta internal seperti latar belakang budaya, pendidikan, pekerjaan, dll. tentunya memberikan pengaruh tersendiri dalam proses pembentukan image sebuah brand. Diakui memang proses penerimaan informasi (information process) sedikit banyak juga dipengaruhi oleh latar belakang budaya seseorang termasuk exposure seseorang akan kampanye produk global itu sendiri.

Melihat dari intensitas akses internet dan media sosial, konsumen terutama yang berada di lingkaran Generasi Y, tidak bisa tidak dipisahkan dari keberadaan ranah digital. Dimana setiap aspek pencarian dan persebaran informasi akan melalui media digital yang memberikan peluang dalam hal kecepatan dan interaktivitas pesanyang kuat. Dalam menyikapi globalisasi, sikap mereka sangat terbuka karena Generasi Y dianggap memiliki level toleransi yang tinggi dalam bersosialisasi dengan orang lain. Mereka juga lebih toleran dalam menyikapi konsep tinggal bersama, pernikahan sejenis, single parents, dll. Sikap toleransi tinggi ini juga memberikan tambahan dalam perspektif mereka menghadapi globalisasi karena mereka dianggap memiliki 'global mix and match culture' (Morton, 2002).

Path dan Facebook masih akan terus mendominasi hingga muncul media sosial lainnya yang menawarkan keunikan tersendiri. Twitter sebagai media sosial juga masih akan bertahan walaupun sedikit sebagai sarana microblogging demi sedikit mulai ditinggalkan oleh penggunanya karena sifatnya yang semakin cepat dan banyak diantara para pengguna tidak mampu menyamai kecepatannya.

Media sosial menjadi salah satu sarana yang tepat bagi Generasi Y karena dalam proses pemasaran Generasi Y tidak menyukai hard sell karena mereka menghargai nilai brand dan juga memiliki kesadaran fashion yang tinggi sehingga mereka selalui memilih brand dengan identitas kuat sebagai nilai utama. Meskipun begitu, generasi ini sangat menghargai rekomendasi orang yang dikenal dalam membeli sesuatu, maka word of mouth merupakansalahsatumetodemarketingyang tepat untuk mereka. Iklan yang menekankan lifestyle dari pada iklan yang detail yang memusingkan. Pada kenyataannya, Generasi 
Y bisa memperoleh informasi mengenai produk itu sendiri melalui banyak sumber (Morton, 2002) dan di masa kini word of mouth yang paling dipercaya adalah melalui media sosial itu sendiri.

Posisi terpaan iklan dalam proses pembentukan keputusan cukup lemah karena telah mengalami berbagai distorsi dalam prosesnya. Selain terpaan media selain internet dan media sosial, tentunya konsumen juga dihadapkan pada ratusan merk lain dengan fungsi yang hampir sama sehingga proses evaluasi alternatif menjadi bagian penting dalam proses pembuatan keputusan, Disinilah brand equity akan berbicara sehingga ketika seseorang telah memiliki nilai akan sebuah brand di benaknya, maka hal ini mampu memberikan dorongan lebih untuk kemudian memilih produk tersebut dibandingkan lainnya.

Saran bagi penelitian selanjutnya, akan sangat menarik apabila peneliti menggali lebih dalam motivasi Generasi Y dalam melakukan pembelian, termasuk penggunaan media internet dan sosial dalam kesehariannya. Apakah memang benar motivasinya untuk meningkatkan kelasnya atau memang mereka tidak menyadari hal tersebut karena bagaimanapun juga internet dan media sosial telah menjadi bagian hidup mereka.

\section{DAFTAR PUSTAKA}

Belk, R.W. 1988. Possessions and theextended self. The Journal of Consumer Research, 15(2), 139-168. Terarsip dalam: http:// www.difi.uniud.it/tl_files/utenti/crisci/ Belk\%201988.pdf.

Bray, J. P., 2008. Consumer Behaviour Theory: Approaches and Models. Terarsip dalam: http://eprints.bournemouth. ac.uk/10107/

De Vaus, D.A. 1991. Survey in Social Research ( $3 r d$ ed.). London: Allen dan Unwin.

Dogerlioglu-Demir, K. dan Tansuhaj, P. 2011. Globalvslocal brand perceptionsamong Thais and Turks. Asia Pacific Journal of Marketing and Logistics, 23(5), 667-683. DOI 10.1108/13555851111183084.

Douglas, S.P. dan Craig, C.S. 1997. The changing dinamyc of consumer behaviour: implications for crosscultural research. International Journal of Research in Marketing, 14, 379-395.

Giddens, A. 1990.The Consequences of Modernity. Cambridge: Polity.

Grazella, M. 2012. Using Viral Power Social Media Marketing. 2012. The Jakarta Post (online). Terarsip dalam: http://www. thejakartapost.com/news/2012/o1/24/ using-viral-power-social-mediamarketing.html

Gurau, C. 2008. Integrated online marketing communication: implementation and management.JournalofCommunication Management, 12(2), 169-184.

Hamidi, N., Pezeshki, P.M. dan Moradian, A. 2010. Weighting the criteria of brand selecting in beverage industries in Iran. Asian Journal of Management Research, 250-267.

Heding, T., Knudtzen, C.F. dan Bjerre, M. 2009. Brand Management: Research, Theory and Practice. New York: Routledge.

Hybels, S. dan Weaver, R.L. II. 2004. Self, perception, and communication. In 
Communicationg Effectively (7th ed.). Boston: McGraw-Hill.

Len, L. 1997. Generation 'Y'. Progressive Grocer, 76(3).

MacInnis, D.J., Moorman, C. \& Jaworski, B.J. 1991. Enhancing and Measuring Consumers' Motivation, Opportunity, and AbilitytoProcess Brand Information from Ads. Journal of Marketing, 55(4),3253.

Majalah Mix (online). 2014. Mendefinisikan Public Relations Masa Depan. Majalah Mix. Terarsip dalam: http://mix.co.id/ public-relations/mendefinisikan-publicrelations-masa-depan/.

McCrindle, M. dan Wolfinger, E. 2010. Generations defined. Ethos, 18(1).

McLuhan, M. and Fiore, Q. 1967.The Medium is the Message: An Inventory of Effects. New York: Bantam.

Miller, K. 2002. Communication Theories: Perspectives, Processes and Contexts. Boston: McGraw-Hill.

Montgomery dan Amstrong. 1970. Brand trial after a credibility change. Journal of Advertising Research,10 (5), 26-32.

Moriarty, S., Mitchell, N. dan Wells, W. 2012. Advertising and IMC: Principles and Practice (gth ed.). New Jersey: Prentice Hall.

Morton, L. 2002. Targeting generation Y. Public Relation Quarterly, 47(2).

Noviandasari, L. 2015. Jumlah pengguna facebook mobile Indonesia tertinggi dunia. Techinasia (online). Terarsip dalam: https://id.techinasia.com/ jumlah-pengguna-facebook-mobileindonesia-tertinggi-dunia (13 April 2015).

Priyatno, D. 2012.Cara Kilat Belajar Analisis Data dengan SPSS 20. Yogyakarta: Penerbit Andi.

Rantanen, T. 2005. The Media and Globalization. London: Sage Publication.
Robertson, R. 1992. Globalization: Social Theory and Global Culture. London: Sage.

Schmitz, A. 2012. A Primer on Communication Studies. Terarsip dalam: http://2012books.lardbucket.org/ books/a-primer-on-communicationstudies/index.html

Seung, A. \& Jin, A. 2014. Following Celebrities' Tweets About Brands: The Impact of Twitter-Based Electronic Word-ofMouthon Consumers'SourceCredibility Perception, Buying Intention, and Social Identification With Celebrities. Journal of Advertising, 43(2), 181-195.

Simmons, G.J. 2007. "i-Branding”: developing the internet as a branding tool. Marketing Intelligence \& Planning, 25(6), 544-562.

Simon, H., Li, H., Martin, S.R. \& Madden, T.J. 2016. The influence of social media interactions on consumer-brand relationships: A three-country study of brand perceptions and marketing behaviors. International Journal of Research in Marketing, 33, 27-41.

Sue, V.M dan Ritter, L.A. 2012. Conducting Online Surveys. Thousand Oaks, California: Sage Publication.

Sun, M.W. 2011. Consumption of luxury fashion brands: the motives of generation $Y$ consumers in China (Master thesis). Terarsip dalam: http://aut.researchgateway.ac.nz/ bitstream/handle/10292/1335/SunM. $p d f$ ? sequence $=3$

Tellis, Gerard J.JMR. 1988. Advertising Exposure, Loyalty and Brand Purchase. Terarsip dalam: http://www.rcf.usc. edu/ tellis/advertising.pdf.

Uyanto, S. 2006. Pedoman Analisis Data dengan SPSS. Yogyakarta: Graha Ilmu.

Widhiarso, W. 2011. Aplikasi analisis kovarian dalameksperimen.ManuskripPublikasi. Fakultas Psikologi Universitas Gadjah Mada. Yogyakarta. 
